\title{
Extrinsic Determinants of Retinal Ganglion Cell Structure in the Cat
}

\author{
Audie G. Leventhal, Jeffrey D. Schall, ${ }^{a}$ and Steven J. Ault \\ Department of Anatomy, University of Utah School of Medicine, Salt Lake City, Utah 84132
}

The degree to which a retinal ganglion cell's environment can affect its morphological development was studied by manipulating the distribution of ganglion cells in the developing cat retina. In the newborn kitten there is an exuberant ganglion cell projection from temporal retina to the contralateral lateral geniculate nucleus (LGNd) (Leventhal et al., 1988) and from nasal retina to the ipsilateral LGNd. Neonatal, unilateral optic tract section results in the survival of many of these ganglion cells (Leventhal et al., 1988). The morphology of ganglion cells which survive in regions of massively reduced ganglion cell density was studied.

As reported previously (Linden and Perry, 1982; Perry and Linden, 1982; Ault et al., 1985; Eysel et al., 1985), we found that the dendritic fields of all types of ganglion cells on the border of an area depleted of ganglion cells extended into the depleted area. The cell bodies and dendritic fields of $\alpha$ and $\beta$ cells within depopulated areas, as well as on the borders of the depopulated areas, were larger than normal. The dendritic fields of these cells also exhibited abnormal branching patterns. For $\alpha$ and $\beta$ cell types the relative increase in size tended to be greatest where the relative change in density was the greatest. In fact, isolated $\beta$ cells within the cell-poor area centralis region resembled normal central $\alpha$ cells in the cell-rich region of the area centralis in the same retina. Interestingly, in the same regions of reduced density where $\alpha$ and $\beta$ cells were dramatically larger than normal, the cell body and dendritic field sizes of other cell types ( $\epsilon$, g1 and g2 were unchanged. These results indicate that neuronal interactions during development contribute to the morphological differentiation of retinal ganglion cells and that different mechanisms mediate the morphological development of different classes of cells in cat retina.

Mammalian retina contains a variety of ganglion cell types exhibiting different forms, functional properties, and central projections (Enroth-Cugell and Robson, 1966; Cleland et al., 1971; Boycott and Wässle, 1974; Cleland and Levick, 1974a, b; Stone and rukuda, 1974). The developmental processes by which ganglion cells differentiate into distinct types remain unknown. Undoubtedly, both intrinsic genetic factors and extrinsic influences contribute. Evidence indicates that the structure of a neuron confers upon the cell many of its receptive field properties both in the retina (Koch et al., 1982) and in central visual structures

\footnotetext{
Received May 21, 1987; revised Oct. 14, 1987 ; accepted Oct. 20, 1987.

Support for this investigation was provided by PHS Grant EY04951 to A.G.L. and NRSA EY05863 to S.J.A. An abstract describing some of these findings has appeared (Ault et al., 1985).

Correspondence should be addressed to Audie G. Leventhal at the above address.

"Present address: Department of Brain and Cognitive Science, E25-634, MIT, Cambridge, MA 02139.

Copyright $(1988$ Society for Neuroscience $0270-6474 / 88 / 062028-11 \$ 02.00 / 0$
}

(Friedlander et al., 1979; Gilbert and Wiesel, 1979). Accordingly, the developmental factors that result in the morphological differentiation of the different classes of retinal ganglion cells must also be responsible for the development of many of the functional properties of the ganglion cells themselves, as well as of the cells in the geniculocortical pathway whose properties reflect those of their afferent ganglion cells.

In the neonatal cat, most, but not all, ganglion cclls in temporal retina project ipsilaterally, whereas virtually all ganglion cells in nasal retina project contralaterally. Neonatal unilateral optic tract section, therefore, depletes the ipsilateral temporal retina of ganglion cells and virtually eliminates ganglion cells in the contralateral nasal retina (Leventhal et al., 1988). We have studied the morphology of retinal ganglion cells that survive optic tract section and develop in regions depleted of neighboring cells.

Our results extend previous work (Linden and Perry, 1982; Perry and Linden, 1982; Eysel et al., 1985) and provide evidence that the morphological differentiation of some classes of ganglion cells in cat retina, the $\alpha$ and $\beta$ cells (Boycott and Wässle, 1974), depend heavily upon postnatal interactions with neighboring neurons, while such interactions do not seem to affect the morphological development of the remaining ganglion cell types to the same degree.

\section{Materials and Methods}

\section{Subjects}

Nine adult cats provided data for this study. All of the animals received unilateral optic tract sections on postnatal day 1. Twelve normal cats provided control data.

\section{Surgery, HRP injection, histology, and histochemistry}

The procedures for the electrophoretic injection of HRP, as well as the histological processing, have been described previously (Leventhal, 1982; Leventhal and Schall, 1983). The procedures employed give Golgi-like filling of labeled cells. Photomicrographs showing the quality of staining obtained are presented in Leventhal (1982).

\section{Ganglion cell classification}

In normal animals, ganglion cells were classified as $\alpha, \beta, \epsilon, \mathrm{gl}$, and $\mathrm{g} 2$ using criteria put forth by Boycott and Wässle (1974) and Leventhal et al. (1985). In experimental animals ganglion cells were classified on the basis of soma and dendritic field size relative to neighboring cells, as well as on axon diameter. In some experimental animals, the HRP injection was limited to the A laminae of the LGNd. Since these layers only receive input from $\alpha$ and $\beta$ cells (Leventhal, 1982), the classification of ganglion cells was unambiguous in these cases.

\section{Morphological analyses}

Cells were drawn under the camera lucida using a $40 \times$ or $100 \times$ oilimmersion objective. The drawing of each cell was traccd onto a digitizing tablet (Houston Instruments) interfaced with a PDP 11/23 computer. The high resolution of the digitizing table $(0.1 \mathrm{~mm})$ provided for 
a very accurate representation of the dendritic field. Each dendritic tree was represented by a series of coordinate points; thicker, proximal trunks were represented by more points than were thin, distal twigs.

Displacement of dendritic field from soma. The centers of the cell body and of the dendritic tree were determined by calculating the mean values of the coordinates representing the cell body and dendritic field, respectively (Leventhal and Schall, 1983; Schall and Leventhal, 1987). The distance separating the center of the dendritic field from the center of the cell body in the plane of the retina was measured. The direction of displacement of the center of the dendritic field from the center of the soma was measured relative to the vertical meridian, which was determined from the distribution of labeled ganglion cells resulting from HRP injections into the LGNd or optic tract.

Segment length and number. The coordinates of the branch and end points of each dendritic tree were stored in the computer. A dendritic segment was defined as the line between successive branch points or between a branch and the end point of a twig. The total number of segments was counted. The length of each segment was measured, and the average length of all the segments comprising the dendritic arbor was calculated.

Dendritic field area. The area of the dendritic field was approximated by the area of an ellipse, with the long axis equal to the diameter of the dendritic field and an elongation equal to that calculated for the dendritic field. Similar measures were applied to the cell bodies.

Neighborhood analysis. The distribution of ganglion cells surrounding each analyzed cell was analyzed quantitatively. The positions of all of the cells of similar and dissimilar type within 4 dendritic field diameters of the ganglion cell under consideration were determined. The position of each neighboring cell was represented with a vector. The angle of the vector was equal to the direction of the neighbor from the reference cell. The length of the vector was inversely proportional to the distance separating the neighbor and the reference cell. The vectors were summed, and the closer neighbors were more heavily weighted due to the length of their vectors. The angle of the resultant vector represented the direction in which the local ganglion cell density was greatest.

\section{Results}

In the cat most, but not all, ganglion cells in temporal retina project ipsilaterally, while virtually all ganglion cells in nasal retina project contralaterally (Stone, 1966). Neonatal optic tract section severely depletes the temporal retina ipsilateral to the section of ganglion cells and virtually eliminates the ganglion cells in the nasal retina contralateral to the section. We have analyzed the morphology of 750 ganglion cells surviving in retinae depleted of ganglion cells. One group of cells was within regions of reduced ganglion cell density; most of these cells were in the temporal retina contralateral to the intact hemisphere, but a few wcre in the nasal retina ipsilatcral to the intact hemisphere. Another group of cells was on the border between ganglion cell dense and ganglion cell sparse zones. The morphological attributes of each cell were related quantitatively to the density and distribution of the cell's neighboring neurons. The structures of more than 1000 ganglion cells in normal retinae, which have been analyzed previously (Leventhal and Schall, 1983; Schall and Leventhal, 1987), provided a normal data base. The results described below provide evidence that profound changes in the structure of some, but not all, types of ganglion cells result from alterations in the distribution of neighboring ganglion cells during development.

\section{Relationship between the ganglion cell density gradient and dendritic displacement}

We analyzed the dendritic structure of 200 well-filled cells in temporal retina on the border between the normal and depleted regions of the retina contralateral to the optic tract section. These cells were filled with HRP injected into the intact LGNd and thus projected ipsilaterally. In optic tract-sectioned animals very few cells in nasal retina project ipsilaterally (Jacobs et al., 1984;
Leventhal et al., 1988); in our material the sharpest border, i.e., steepest ganglion cell density gradient, is found along the nasotemporal division in the retina contralateral to the optic tract lesion (Leventhal et al., 1988). It is for this reason that the contralateral retina was chosen for this analysis.

In agreement with the observations of Linden and Perry (1982), Perry and Linden (1982), and Eysel et al. (1985), we find that, on the border between normal regions and regions depleted of ganglion cells, the dendritic fields of all cell types extend preferentially into the depleted area. We analyzed this phenomenon quantitatively by relating the distribution of each cell's dendrites relative to its cell body to the spatial distribution of neighboring neurons of like type. The angle difference was measured between the direction of dendritic displacement from the cell body and the direction of peak local density. This angle difference can range from $0^{\circ}$ to $\pm 180^{\circ}$, with a difference near $0^{\circ}$ indicating displacement toward the local density and a difference near $\pm 180^{\circ}$ indicating displacement away from local density. As shown in Figure 1, there is a significant tendency for the center of the dendritic field of ganglion cells on the border of a depleted area to be displaced away from the point of highest local density. This was true for $\alpha$ cells ( $V$ test $U=3.34, p<0.0005$ ), $\beta$ cells $(U=11.95, p<0.0005)$, and $\epsilon$ cells $(U=2.69, p<0.005)$. The relatively few cells of other types that were sufficiently well filled to study quantitatively also tended to be directed away from neighboring cells. It must be pointed out that this result does not imply that the distribution of neighboring ganglion cells of different types is irrelevant. In virtually all cases the local distribution of neighboring neurons of like and of unlike type were similar. We have also analyzed the dendritic displacement relative to the distribution of all cells regardless of type, and the results are not different. Thus, as with previous studies, our results do not provide direct evidence that the effects observed are class specific.

\section{Relationship between ganglion cell density and soma size}

Ganglion cells that developed in areas of retina depleted of other ganglion cells tended to be larger than their normal counterparts. The magnitude of the increase in size varied with retinal position and across cell types, as indicated in Figure 2 . The cell body sizes of $\beta$ cells in the part of the area centralis depleted of ganglion cells (Fig. $2 F$ ) are significantly larger that $\beta$ cells (Fig. $2 E$ ) in corresponding regions of normal density. Similarly, isolated central $\alpha$ cells (Fig. 2D) are much larger than their normal counterparts (Fig. 2C). Such differences are not as pronounced for $\alpha$ and $\beta$ cells in peripheral retina (Fig. 2, $A$ and $B$ ). Notice that while both $\alpha$ and $\beta$ cells increase dramatically in size, the relative differences between the 2 cells are preserved. Adjacent $\alpha$ and $\beta$ cells in cell-poor regions were both abnormally large, but isolated $\alpha$ cells were still far larger than isolated $\beta$ cells. Thus, identifying the cells as $\alpha$ and $\beta$ was straightforward. The cell bodies of other types of ganglion cells $-\epsilon, \mathrm{g} 1$, and $\mathrm{g} 2$ (Fig. $2, A-D)$-in areas of reduced ganglion cell density were not larger than normal.

These data were analyzed quantitatively by measuring various morphological parameters for a large number of ganglion cells from areas of retina with normal and experimentally reduced density. In Figure 3 the cell body areas of $\alpha, \beta, \epsilon$, and the remaining ganglion cell types in contralateral temporal retina are plotted as a function of eccentricity. Notice that there are differences in the effects of cell density on soma size across the 

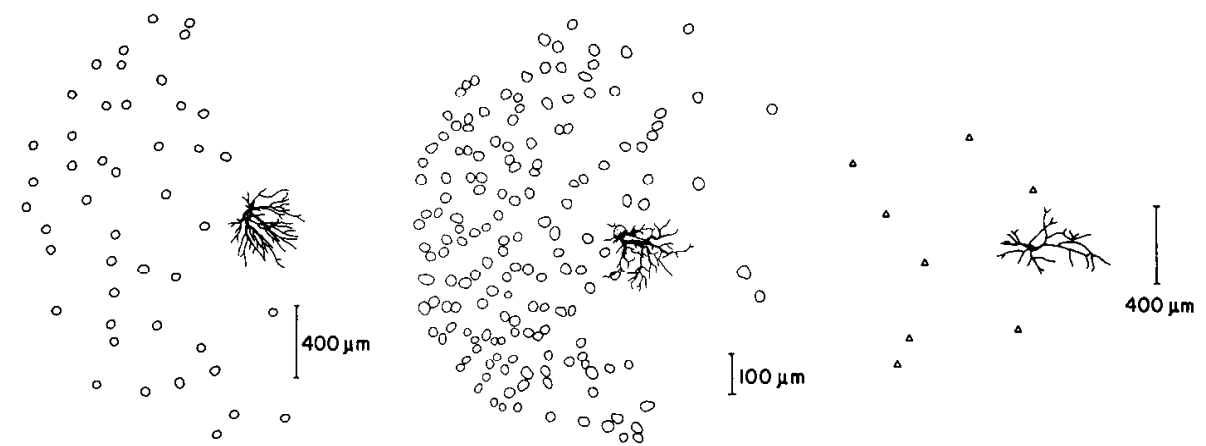

Figure 1. Displacement of ganglion cell dendritic fields in relation to local distribution of ganglion cells of the same morphological type. Top row, Structurc of representative $\alpha, \beta$, and $\epsilon$ ganglion cells from left to right; in each panel only the cell bodies of cells of like type are outlined. Below, Histograms illustrating the distribution of angle differences between the direction of dendritic displacement and the direction of peak density for the different cell types. Displacement direction is the angle of the center of the dendritic field from the center of the cell body. Neighborhood direction is the angle from the center of the cell body of the cell under investigation to the point of peak local density. An angle difference of $0^{\circ}$ indicates that the dendritic field is displaced toward the densest point, and an angle difference of $180^{\circ}$ indicates dendritic displacement away from local density. For $\alpha, \beta$, and $\epsilon$ cells it is evident that the dendritic fields tend to be displaced away from neighboring cells.

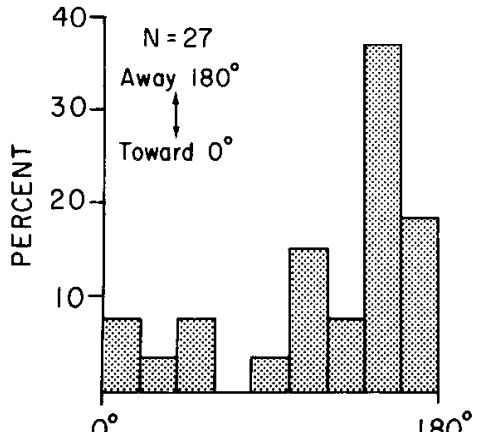

DISPLACEMENT DIRECTION - NEIGHBORHOOD DIRECTION
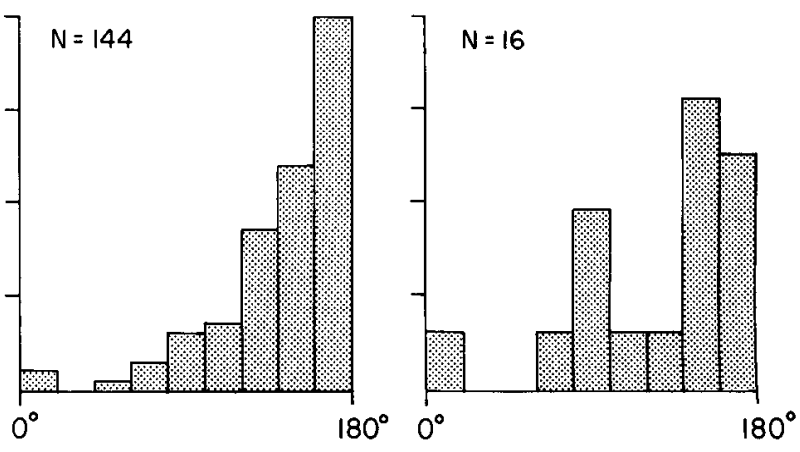

$180^{\circ}$ retina and across cell types. The cell bodies of $\alpha$ cells that develop in areas of reduced cell density were significantly larger than normal at all eccentricities. The relative increase in size, however, decreases with eccentricity. For example, the mean soma area of normal $\alpha$ cells within $1 \mathrm{~mm}$ of the area centralis was $669 \mu \mathrm{m}^{2}$, and the mean area of isolated $\alpha$ cells ${ }^{1}$ at the same eccentricity was $1121 \mu \mathrm{m}^{2}$. This represented an average increase of $67 \%$ ( $t$ test, $t=7.5, d f=81, p<0.001)$, and cell bodies more than 3 times larger than normal were observed. In contrast, the increase in soma area of $\alpha$ cells more than $3 \mathrm{~mm}$ from the area centralis was somewhat less, $56 \%$, from 1182 to $1847 \mu \mathrm{m}^{2}(t=$ $8.4, d f=54, p<0.001)$, with the greatest increase observed being 2.2 times larger than normal. Similar results were observed for $\beta$ cells. The increase in soma area of $\beta$ cells within 1 $\mathrm{mm}$ of the area centralis was $79 \%$, from 218 to $390 \mu \mathrm{m}^{2}(t=$ $15.2, d f=164, p<0.001)$. Within the cell-free region of the area centralis, cell bodies up to 2.8 times larger than normal were observed. The mean increase in soma area of $\beta$ cells more than $3 \mathrm{~mm}$ from the area centralis was $32 \%$, from 481 to 637 $\mu \mathrm{m}^{2}(d f=93, t=8.4, p<0.001)$, with the greatest observed increase being 1.7 times larger than normal. In contrast to the effects of reduced cell density on $\alpha$ and $\beta$ cells, the cell bodies of $\epsilon$ and other ganglion cell types with small cell bodies that developed in areas of reduced ganglion cell density were not larger than normal.

It has been reported that about $50 \%$ of $\gamma$ cells in temporal retina project contralaterally in the normal cat (Wässle and Illing, 1980). Consequently, neonatal optic tract section should not reduce the density of this cell type to the same extent as it

' The size of the experimental cells was more variable than normal. A significant degree of this variability can be accounted for by the fact that experimental cells were sampled from regions in which ganglion cell density was reduced by different degrees. Typically, the greatest increase in cell size was observed in cells that were most isolated (see Fig. 6). does the other cell types. This should not affect the results presented here. Since all of the retinae studied were counterstained, we only analyzed $\mathrm{g} 1$ and $\mathrm{g} 2$ cells in regions in which the density of small cells was truly reduced. Nevertheless, to make certain that the size of these cells does not increase in areas of reduced density, we also analyzed the size of the ipsilaterally projecting g1 and 2 cells in nasal retina which survived optic tract section (Jacobs et al., 1984). These were the most "isolated" cells in our sample; we found only $20-40$ labeled cells in the ipsilateral nasal retina following injections in the LGNd of normal and sectioned cats (Leventhal et al., 1988). As illustrated in Figure 4 , the size of these cells did not change with retinal eccentricity and ipsilaterally projecting cells in nasal retina of sectioned cats $\left(n=58\right.$; mean $( \pm \mathrm{SD})$ area, $\left.217 \pm 44.3 \mu \mathrm{m}^{2}\right)$ were not significantly larger than normal ( $n=81$; mean area, $\left.191 \pm 68.5 \mu \mathrm{m}^{2}\right)$.

In order to demonstrate that the relationship between cell body size and the density of neighboring cells was independent of retinal position, we related the cell body sizes of $\beta$ cells within a restricted region near the area centralis to the local density of neighboring $\beta$ cells (Fig. 5). We found that within $1 \mathrm{~mm}$ of the center of the area centralis in normal and cell-poor regions of the retina, the soma size of $\beta$ cells was related to the decrease in local cell density. The variability of cell size as a function of cell density was accounted for best by a third-order polynomial regression $(R=0.9, p<0.001)$. In fact, $\beta$ cells in areas of reduced cell density within $1 \mathrm{~mm}$ of the area centralis have cell bodies as large as their counterparts in far peripheral areas of retina where similar numbers of neighboring $\beta$ cells are normally found. This indicates that cell density, and not retinal position per se, is more important in determining the size of the cell body.

\section{Relationship between ganglion cell density and dendritic field structure}

The effects of reduced ganglion cell density on dendritic field morphology are demonstrated in Figure 6 , in which $\alpha$ and $\beta$ 

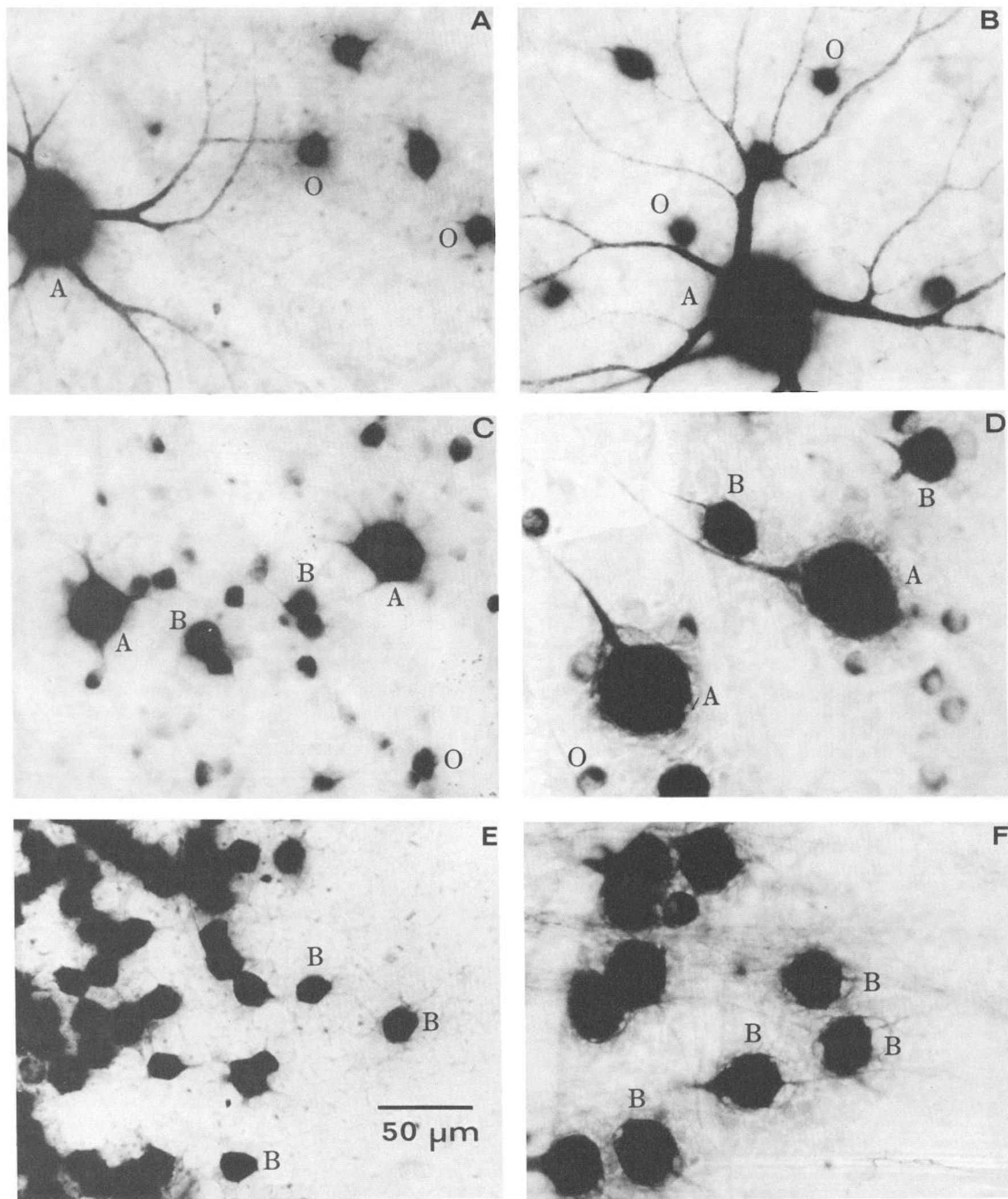

$\mathbf{E}$

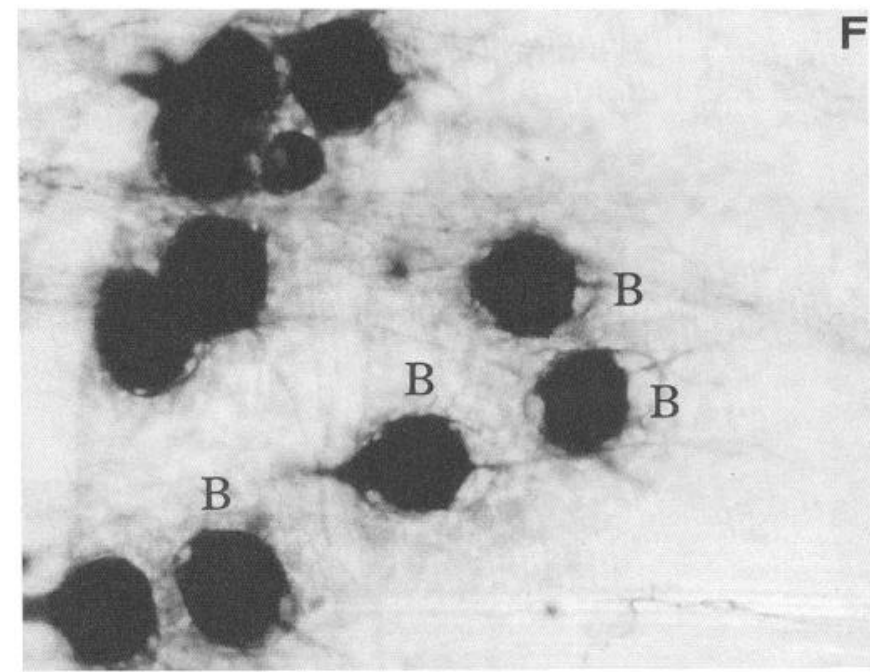

Figure 2. HRP-labeled ganglion cells in areas of normal and reduced ganglion cell density. $A$, $C$, and $E$, Cells in areas of normal cell density; $B$, $D$, and $F$, Cells in areas of experimentally reduced ganglion cell density. $A$ and $B$ are from peripheral retina; $C-F$ are from central retina. Some examples of $\alpha(A), \beta(B)$ and other $(O)$ types of cells are indicated. All of the cells labeled in $E$ and the larger cells in $F$ are $\beta$ cells. The largest cells in $C$ and $D$ are $\alpha$ cells, the medium-sized are $\beta$ cells, and the smallest are other types. The largest cells in $A$ and $D$ are $\alpha$ cells; the other cells are $\beta$ cells. $\alpha$ and $\beta$ cells in regions of reduced density are larger than normal; the increase in cell size is more pronounced in central than in peripheral retina. Also, $\alpha$ and $\beta$ cells exhibit changes in size, while the remaining cell types do not. 
Figure 3. Cell body area versus eccentricity. Each point represents the measure for an individual cell; all cells were sampled in the temporal retina contralateral to the intact hemisphere. Solid circles show normal cells; open circles, experimentally affected cells. It is evident that the cell bodies of $\alpha$ and $\beta$ cells that develop in areas of reduced cell density are larger than normal at all eccentricities but that the relative difference decreases with eccentricity. In contrast, the cell bodies of $\mathrm{e}$ and other cell types that develop in areas of reduced cell density are no different from normal.

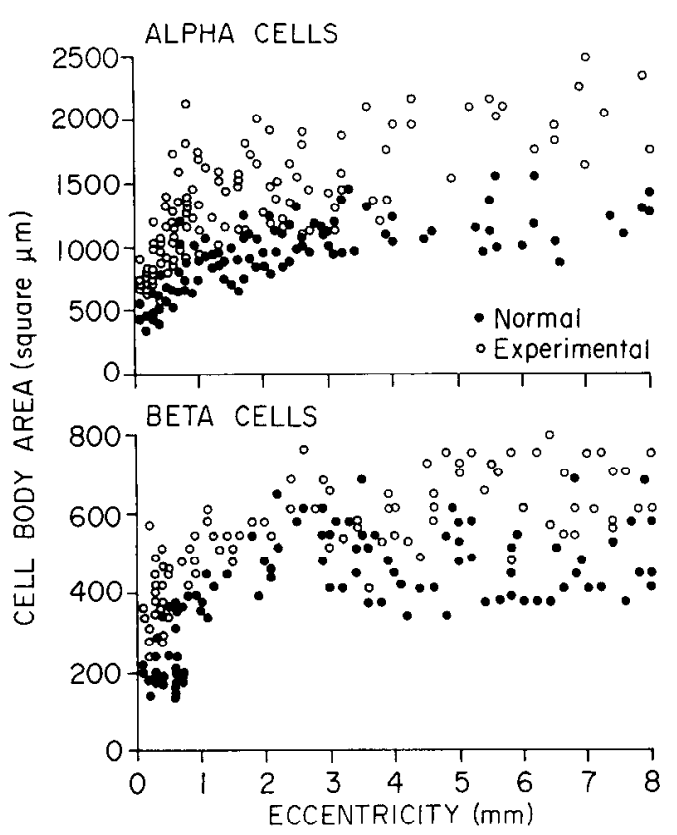

cells from corresponding points of retina with normal and experimentally reduced ganglion cell density are compared. It is evident from the results that the dendritic field area of cells in regions of reduced ganglion cell density is larger than that of normal counterparts.

Figure 7 illustrates the changes in dendritic field area with eccentricity for isolated and normal ganglion cells. Results are presented for $\alpha, \beta$, and $\epsilon$ cells. There were not enough ganglion cells of other types sufficiently well filled with HRP to evaluate dendritic morphology quantitatively. It is evident that $\alpha$ and $\beta$ cell dendritic fields that develop in areas of reduced ganglion cell density are significantly larger than normal. Isolated $\alpha$ cell dendritic fields less than $3 \mathrm{~mm}$ from the area centralis were, on average, 92\% larger than normal $(t=2.9, d f=54, p<0.01)$; the largest observed increase was nearly 5.4 times normal. Isolated $\alpha$ cell dendritic trees more than $3 \mathrm{~mm}$ from the area cen-

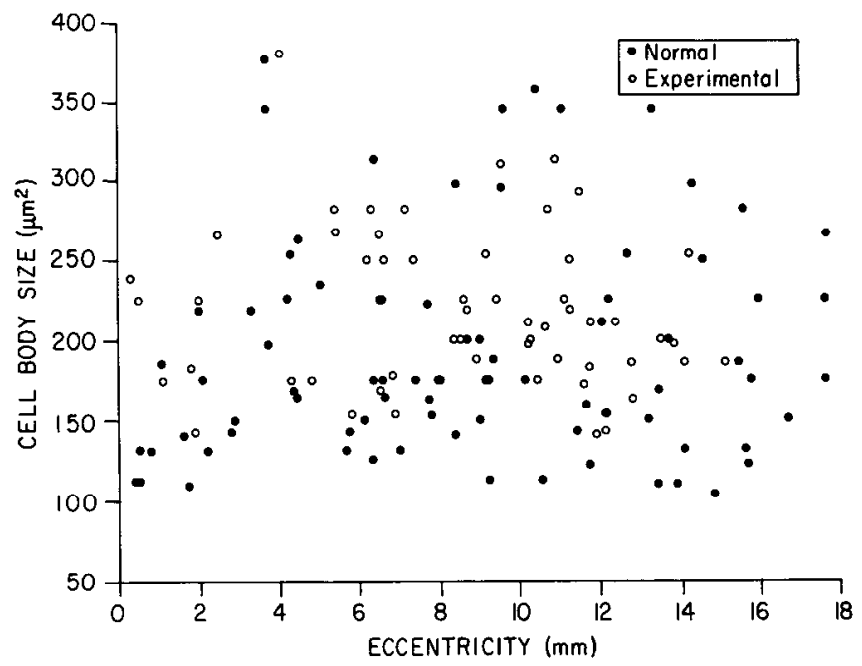

Figure 4. Cell body area versus eccentricity for isolated ipsilaterally projecting $\mathrm{g} 1$ and $\mathrm{g} 2$ cells in nasal retina of normal and optic tract sectioned cats. Conventions are as in Figure 3 . The cell bodics of $g 1$ and $\mathrm{g} 2$ cells that develop in areas of reduced cell density are not significantly larger than normal. tralis averaged $89 \%$ larger than normal $(t=7.3, d f=80, p<$ 0.001 ), with the largest dendritic field measuring 3.2 times larger than normal. Isolated $\beta$ cell dendritic fields less than $3 \mathrm{~mm}$ from the area centralis were, on average, $264 \%$ larger than normal $(t=7.6, d f=61, p<0.001)$; the largest dendritic field was over 9 times larger than normal. The average increase in dendritic field area of isolated $\beta$ cells more than $3 \mathrm{~mm}$ from the area centralis was $170 \%(t=6.8, d f=78, p<0.001)$, and dendritic fields up to 5.8 times larger than normal were observed. In agreement with the results for cell body sizc, $\epsilon$ cell dendritic fields in depleted areas were not larger than normal. The dendritic fields of the few well-filled examples of other ganglion cell types in regions of reduced cell density were within normal limits.

Since the dendritic fields of $\alpha$ and $\beta$ cells in depleted areas of retina were so much larger than their normal counterparts, the branching pattern of the dendritic arbor was analyzed in more detail. Figure 8 shows the change in the number of segments comprising the dendritic tree as a function of eccentricity for normal and experimentally altered $\alpha, \beta$, and $\epsilon$ cells. Isolated $\alpha$ cells less than $3 \mathrm{~mm}$ from the area centralis had only $5 \%$ more segments than normal $(t=0.5, d f=32, p>0.1)$. Isolated $\alpha$ cell dendritic fields more than $3 \mathrm{~mm}$ from the area centralis averaged $31 \%$ more segments than normal $(t=3.7, d f=40, p<0.001)$. Isolated $\beta$ cells less than $3 \mathrm{~mm}$ from the area centralis had $98 \%$ more segments than normal $(t=10.1, d f=119, p<0.001)$. Isolated $\beta$ cell dendritic arbors more than $3 \mathrm{~mm}$ from the area centralis had on average $28 \%$ more segments than normal $(t=$ $2.9, d f=85, p<0.01$ ). The number of segments in $\epsilon$ cell dendritic fields in depleted areas was not different from normal. The number of dendritic segments in the examples of other ganglion cell types, which were in areas of reduced density, appeared normal.

The changes in the length of dendritic segments of $\alpha, \beta$, and $\epsilon$ cells is demonstrated in Figure 9. Isolated $\alpha$ cell dendritic fields less than $3 \mathrm{~mm}$ from the area centralis exhibited segments $19 \%$ longer, on average, than normal ( $t=3.6, d f=32, p<0.01$ ). We observed isolated, central $\alpha$ cells with a mean dendritic segment length more than 1.5 times longer than their normal 


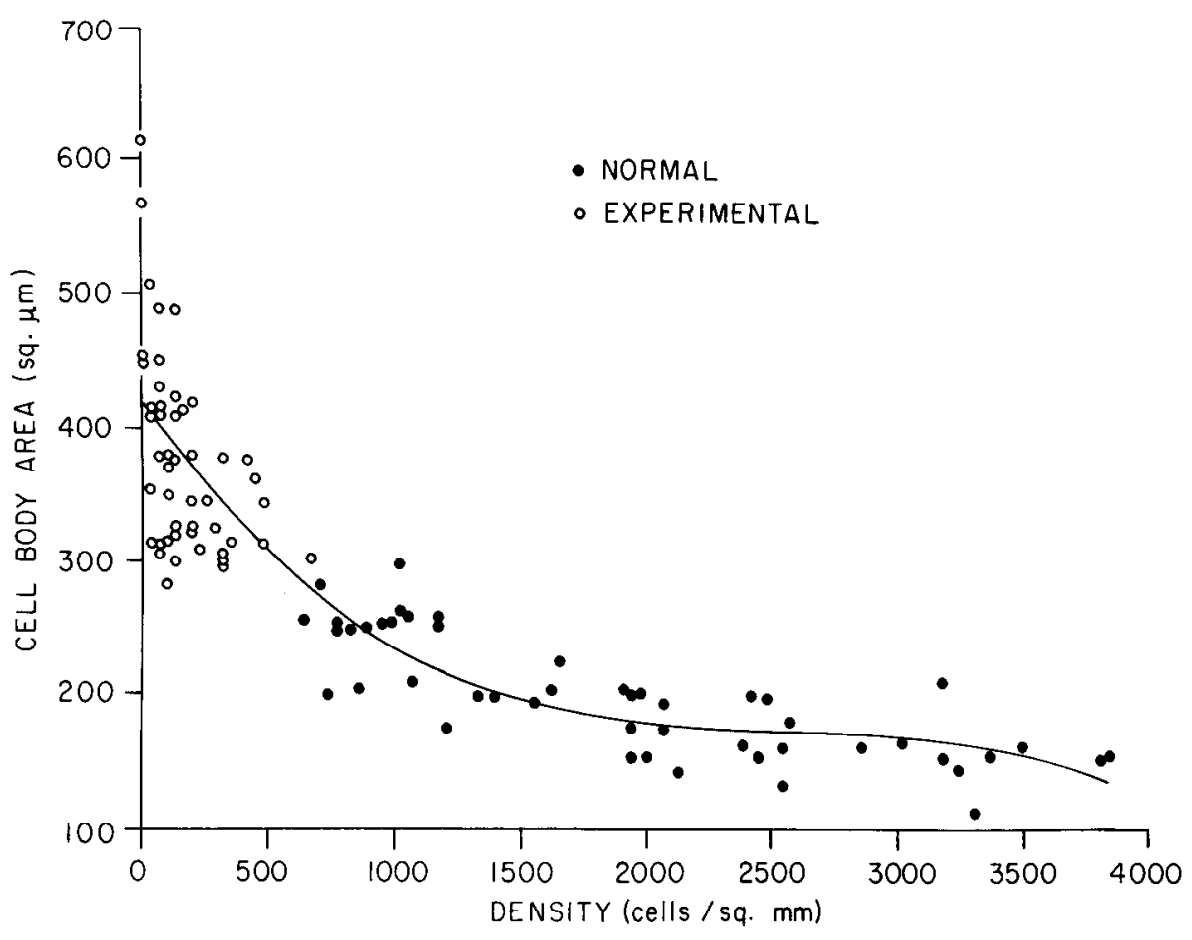

Figure 5. Cell body area versus cell density for $\beta$ cells in normal and experimentally depleted regions within 1 $\mathrm{mm}$ of the area centralis. Conventions are as in Figure 3. The line passing through the data points is a third-order polynomial regression. It is clear that soma size increases dramatically as the density of neighboring $\beta$ cells decreases within a restricted region of central retina. The data indicate that cell density, not retinal position per se, determines cell size. counterparts. Isolated $\alpha$ cells more than $3 \mathrm{~mm}$ from the area centralis had dendritic segments that averaged $30 \%$ longer than normal $(t=4.2, d f=40, p<0.001)$, and we observed increases over the average length of nearly 1.8 times. The dendritic trees of isolated $\beta$ cells less than $3 \mathrm{~mm}$ from the area centralis had a mean segment length $46 \%$ longer than normal $(t=6.0, d f=$ $119, p<0.001)$. In our sample, the greatest observed increase in average dendritic segment length of isolated, central $\beta$ cells was 3.3 times greater than normal. Isolated $\beta$ cell dendritic arbors more than $3 \mathrm{~mm}$ from the area centralis were comprised of segments that averaged just $17 \%$ longer than normal $(t=1.9$, $d f=83, p<0.01)$. The largest increase in mean segment length of isolated, peripheral $\beta$ cells was about 1.8 times greater than the average normal valuc. The avcrage length of the segments comprising $\epsilon$ cell dendritic fields in areas of reduced ganglion cell density was not different from normal. The few well-filled, isolated examples of other ganglion cell types also appeared normal in this regard.

\section{Discussion}

This study has shown that the morphology of cat retinal ganglion cells is influenced by the density and distribution of neighboring ganglion cells during development. The specific results are summarized below.

1. As has been shown previously (Linden and Perry, 1982; Perry and Linden, 1982; Eysel et al., 1985), we find that the direction of displacement of the dendritic field from the cell body of $\alpha, \beta$, and $\epsilon$ cells is determined by the distribution of neighboring cells; the center of the dendritic field is displaced down the experimentally induced density gradient, i.e., away from other cells.

2. If ganglion cell density is reduced by neonatal, unilateral optic tract section, then the cell bodies and dendritic fields of $\alpha$ and $\beta$ cells, but not of other types of ganglion cells, grow to be abnormally large. The increase in size is most pronounced in central retina, where the reduction in ganglion cell density is greatest. In the ganglion cell-free area centralis region, isolated $\beta$ cells bear a morphological resemblance to $\alpha$ cells in the same retina in the region of the area centralis containing normal numbers of $\alpha$ and $\beta$ cells.

3. In all regions of the ganglion cell-poor hemiretina, isolated $\alpha$ cells always have larger cell bodies and dendritic fields than

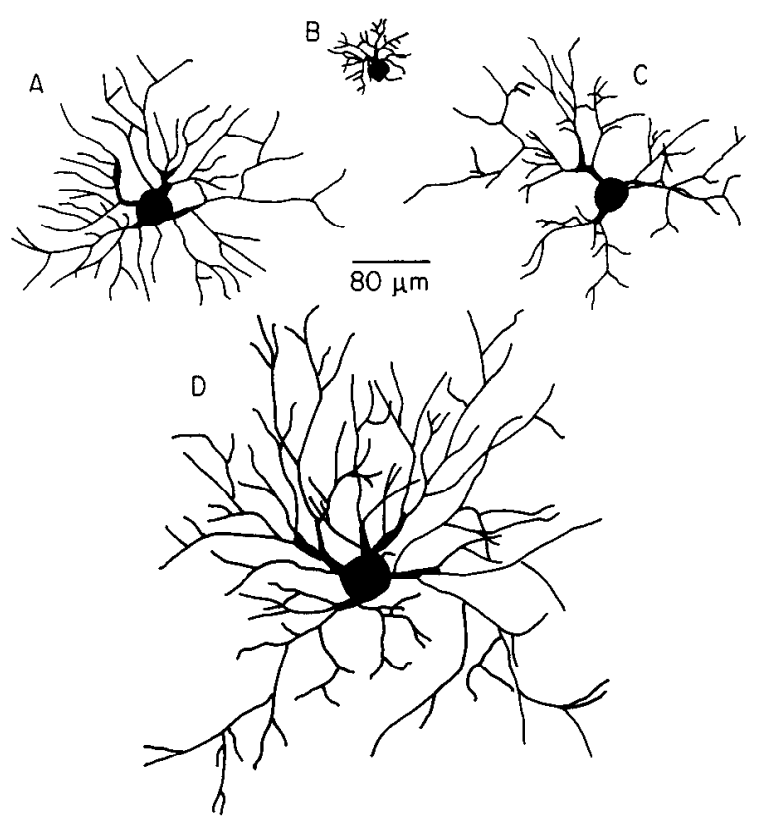

Figure 6. Camera lucida drawings of HRP-filled ganglion cells in corresponding retinal areas of normal and reduced ganglion cell density. $A$, normal $\alpha$ cell; $B$, normal $\beta$ cell; $C, \beta$ cell from area of reduced density; $D, \alpha$ cell from area of reduced density. Each of these cells was approximately $1 \mathrm{~mm}$ from the center of the area centralis. $\alpha$ and $\beta$ cells that developed in areas of reduced density have significantly larger dendritic fields than normal. Also notice the morphological similarity between the normal central $\alpha$ cell $(A)$ and the isolated central $\beta$ cell $(C)$. 

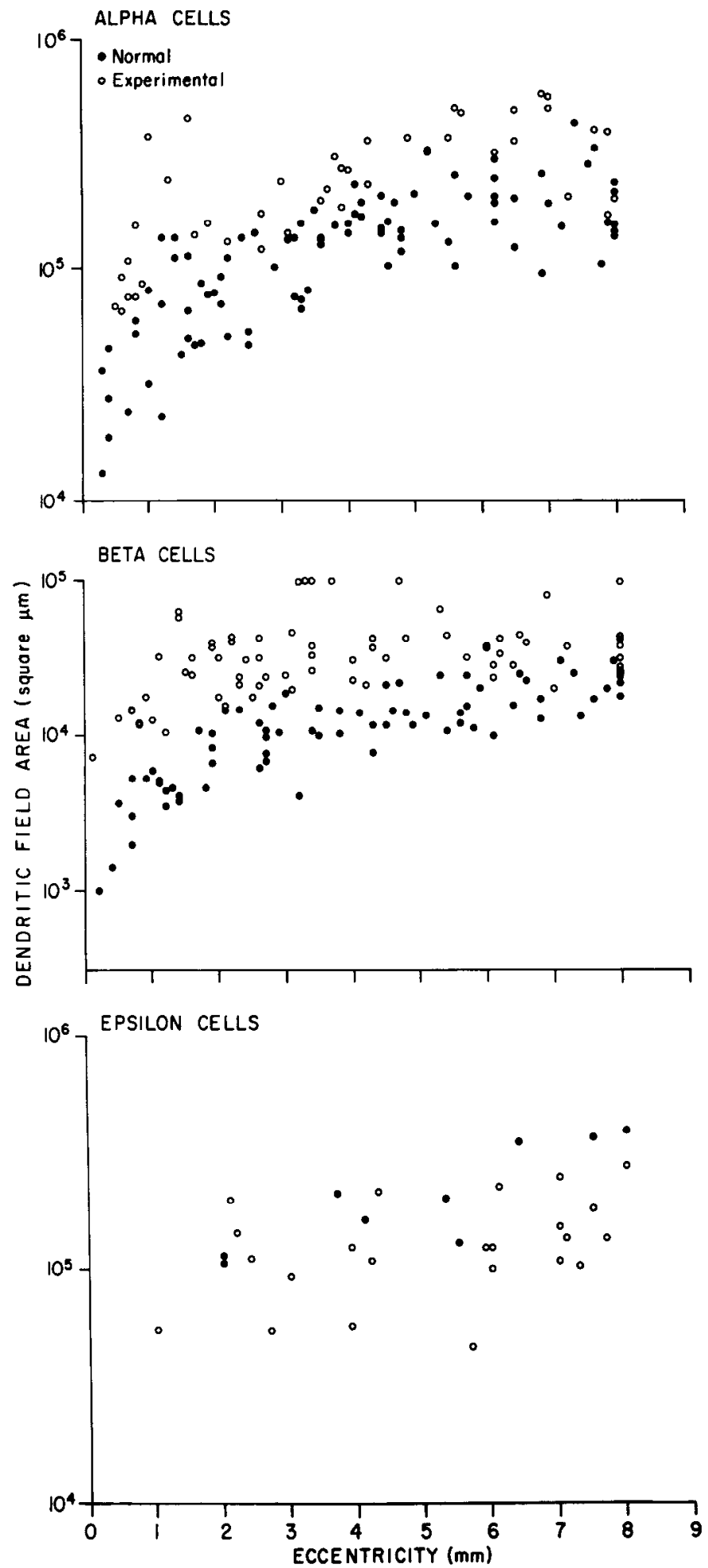

Figure 7. Dendritic field area versus eccentricity for $\alpha, \beta$, and $\epsilon$ cells. Conventions are as in Figure 3. Note that $\alpha$ and $\beta$ cell dendritic fields that develop in areas of reduced ganglion cell density are larger than normal and that the relative increase in size decreases with eccentricity. $\epsilon$ cell dendritic fields that develop in areas depleted of ganglion cells are not larger than normal.

do nearby, isolated $\beta$ cells. Thus, while the absolute sizes of $\alpha$ and $\beta$ cells that develop in areas of reduced density increased dramatically, the relative differences between the 2 cell types were always maintained.
4. The increase in the dendritic field sizes of $\alpha$ and $\beta$ cells was due to both an increase in the length and number of dendritic scgments.

5. The sizes of $\epsilon$ cells and ganglion cells with small cell bodies that developed in the depleted hemiretinae were not different from normal.

\section{Changes in morphology associated with retinal eccentricity}

The present results suggest that the well-documented increase in cell body and dendritic field size of $\alpha$ and $\beta$ cells associated with increasing distance from the area centralis in the normal retina (Boycott and Wässle, 1974; Kolb et al., 1981; Leventhal, 1982) is in large part due to the decrease in the density of ganglion cells normally associated with eccentricity, as suggested previously by Wässle et al. (1981a). Our finding that isolated $\beta$ cells in the area centralis region resemble their normal peripheral counterparts supports this idea. Also consistent with this hypothesis is the finding that the morphology of cell types other than $\alpha$ and $\beta$ cells normally change little with eccentricity (Boycott and Wässle, 1974), and we find that the cell body and dendritic field sizes of these cells are not significantly affected by a reduction in the number of neighboring cells.

Eysel et al. (1985) investigated the morphology of retinal ganglion cells on the borders of cell-free regions that resulted from pinpoint lesions close to the optic disk in neonatal cat retina. These authors reported that cells at the borders of ganglion cellfree areas are not larger than normal. On the basis of these results, they suggested that changes in ganglion cell morphology associated with eccentricity are determined intrinsically and are unrelated to neuronal interactions during development.

We believe that the differences in the results of the present investigation and the one of Eysel et al. (1985) are more apparent than real and in all likelihood reflect 2 technical differences between the studies. First, Eysel et al. made short pressure injections of HRP in conjunction with a neurofibrillar stain to visualize the ganglion cells. They only obtained good filling of $\alpha$ cells and thus reported results primarily for this cell type. In contrast, we made extremely long (up to $24 \mathrm{hr}$ ) electrophoretic HRP injections. In our experience this technique provides for excellent filling of $\alpha, \beta$, and $\epsilon$ cells. We were therefore able to study a number of other cell types.

Second, we caused ganglion cell degeneration by making unilateral optic tract lesions and thus were able to study morphological changes associated with reduced ganglion cell density in central and peripheral retina. We find that the morphological changes associated with reduced cell density are less pronounced in the periphery. Because Eysel et al. made retinal lesions close to the optic disk, they were constrained to look only in peripheral retina, where the changes in cell morphology are smallest. In summary, then, it is not surprising that Eysel et al. failed to note the changes we observed since the cells they emphasized were peripheral $\alpha$ cells, which we also find show relatively small changes in morphology (Figs. 3 and 5). In our material, central $\beta$ cells showed the largest percentage increase in cell body and dendritic field size.

In consonance with our findings, 2 other recent investigations have demonstrated increases in ganglion cell body size following experimental reduction in ganglion cell density in the cat ( $\mathrm{Ra}-$ paport and Stone, 1983) and rat (Carpenter et al. 1986). Results complementary to ours have been provided by Kirby and Chalupa (1986); they demonstrated that when ganglion cell density is increased by prenatal enucleation, $\alpha$ cell soma and dendritic 


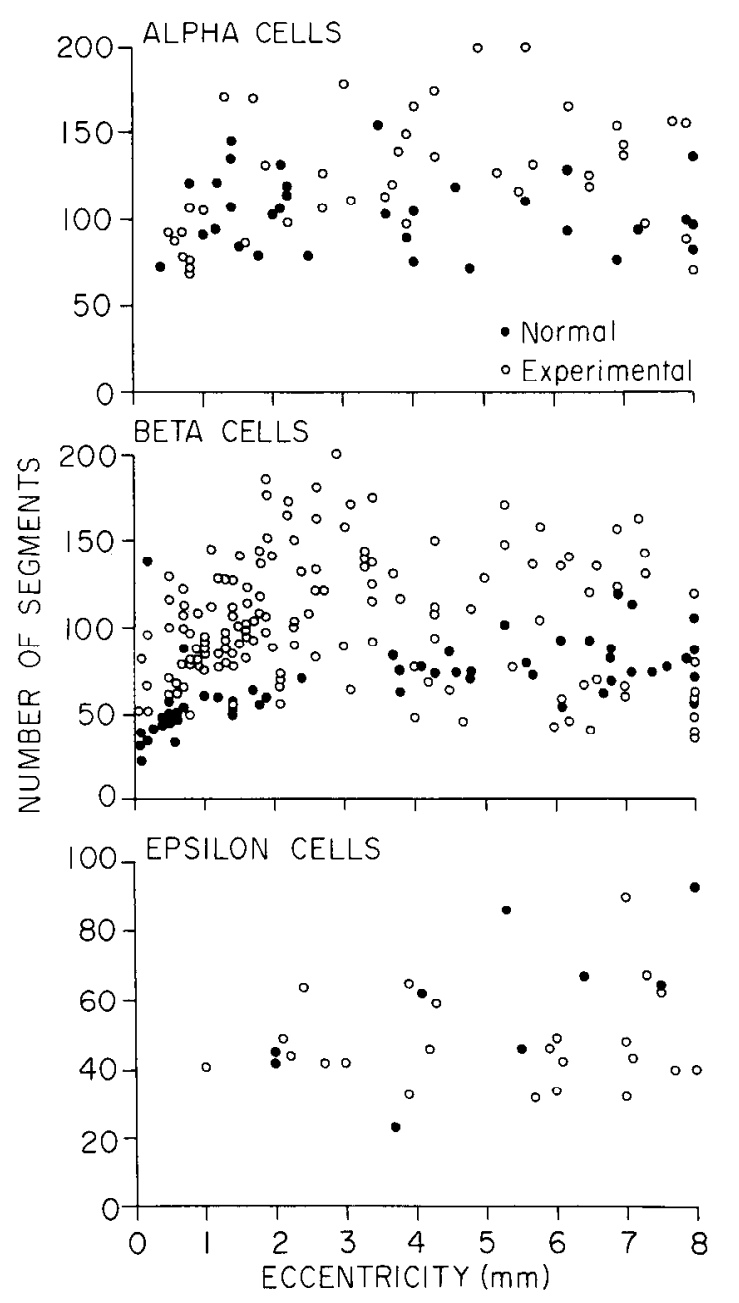

Figure 8. Dendritic segment number versus eccentricity for $\alpha, \beta$, and $\epsilon$ cells. Conventions are as in Figure 3. $\alpha$ and $\beta$ cell dendritic fields that develop in areas of reduced ganglion cell density have more segments than normal. $\epsilon$ cell dendritic fields that develop in areas depleted of ganglion cells do not have more segments than normal.

fields are smaller than their normal counterparts at the corresponding eccentricity but equivalent in size to their counterparts at the corresponding density. Hence, the foregoing data, taken together, support the notion that the ganglion cell size changes associated with eccentricity are largely, if not entirely, due to neuronal interactions that occur during development of the normal retinal ganglion cell density gradient.

\section{Relation to other neuronal systems}

It is important to recognize that the mechanisms of dendritic growth revealed by our experiments on retinal ganglion cells are probably not different from the mechanisms occurring in other parts of the nervous system. Whereas in the retina it has been possible to deplete the number of neighboring ganglion cells, and thus to provide ganglion cells with more afferents than normal, in other parts of the nervous system it is possible to remove the afferents to a group of cells. It is well documented that reducing the number of afferents results in fewer, shorter dendritic branches. For example, elimination of the granule cells in the cerebellum results in a reduced distal arbor of Purkinje cell dendrites (Altman and Anderson, 1972; Rakic and Sidman, 1973a, b; Sotelo and Changeux, 1974; Sotelo, 1975; Altman,

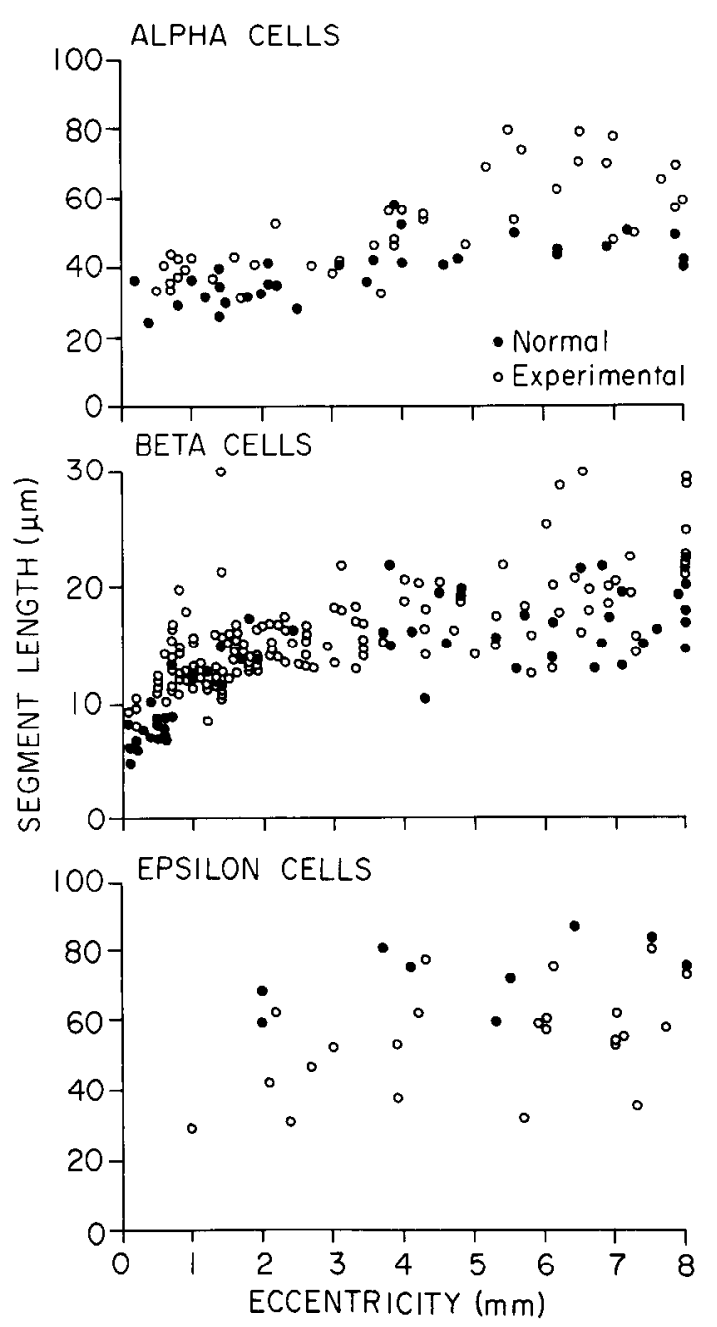

Figure 9. Dendritic segment length versus eccentricity for $\alpha, \beta$, and $\epsilon$ cells. Conventions are as in Figure 3. $\alpha$ and $\beta$ cell dendritic fields that develop in areas of reduced ganglion cell density have longer segments than normal. $\epsilon$ cell dendritic fields that develop in areas depleted of ganglion cells do not have longer segments than normal.

1976; Bradley and Berry, 1976; Mariani et al., 1977). Elimination of the climbing fibers results in a decrement in the proximal dendrites of Purkinje cells (Bradley and Berry, 1976; Sotelo and Arsenio-Nunes, 1976). Elimination of the cochlear nerve input to brain-stem auditory nuclei results in reduced dendritic growth (Parks, 1981; Deitch and Rubel, 1984).

The foregoing investigations have considered the overall dendritic shape. However, there is an example in another system of the experimental induction of directed dendritic growth that may be analogous to what we have observed in the retina. Specifically, in layer 4 of the rodent somatosenory cortex the cells are arranged in "barrels" corresponding to the distribution of facial vibrissae (Woolsey and Van der Loos, 1970). The dendritic trees of cells on the rim of a barrel extend into the center of the barrel (Woolsey et al., 1975). If a row of vibrissae is removed in the neonate, the corresponding barrels coalesce, and the dendritic fields adjust their spatial distribution accordingly (Steffan and Van der Loos, 1980; Harris and Woolsey, 1981). In these studies as well as the present one, the dendritic field structure may be determined by "competition" for afferents or trophic substances, as well as by more direct interactions with neighboring cells of like type. 


\section{Retinal ganglion cell class differences}

While the present study provides evidence that intcractions bctween neighboring ganglion cells during development contribute to the size differences evident among ganglion cells, our results also indicate that many of the relative differences between cell types develop independently of such interactions. In particular, we have observed many instances in which central $\alpha$ and $\beta$ cells were close to each other in an area of reduced ganglion cell density. These cells were far larger than normal. However, in all cases, isolated $\alpha$ cells were far larger than the adjacent isolated $\beta$ cells; the relative differences between the cell body and dendritic field sizes were maintained for the 2 classes.

In view of this, a number of questions arise. First, why do isolated $\alpha$ cells grow to be larger than adjacent, isolated $\beta$ cells? Second, why do isolated $\beta$ cells grow only slightly larger than normal peripheral $\beta$ cells even though the density of $\beta$ cells in the depleted hemiretina is much lower than in normal peripheral retina? Third, why do not $\epsilon, \mathrm{g} 1$, and $\mathrm{g} 2$ cells grow to be abnormally large?

At least 3 answers to these questions come to mind. The first is that some of the differences between ganglion cells are genetically determined. Our observation that changes in the density of neighboring neurons during development affect the sizes of $\alpha$ and $\beta$ cells but not other cell types supports this, since it shows that different factors mediate the development of different cell types. Several lines of evidence are consistent with there being genotypic distinction of the different ganglion cell types. For example, different ganglion cell types differentiate at different times (Walsh and Polley, 1985). The different ganglion cell types exhibit different membrane proteins, as revealed by the selective staining of the CAT-301 monoclonal antibody (Hendry et al., 1984). The synaptic connections of the different ganglion cell types within the retina are different (Kolb, 1979; Stevens et al., 1980). It will be a formidable task to ascertain which aspects of ganglion cell morphology are intrinsically specified and which are determined by factors in the molecular environment of the developing retina.

Another possibility is that many of the differences between ganglion cell types are not genetically specitied, but rather result from interactions not revealed by the present study. For example, it is possible that different cell types mature at different times and that the cell's retinal environment varies during development. Thus, cells with similar genetic makeup may develop quite differently since the extrinsic factors to which they are exposed during development vary. It is also quite possible that our manipulations were done too late in the course of retinal development to affect certain aspects of ganglion cell morphology. In fact, $\alpha, \beta$, and other cell types are morphologically distinct in neonatal kittens (Maslim et al., 1986; Ramoa et al., 1987), so class-related differences already exist at the time of our optic tract section. It should be possible to test whether some or all of the relative differences in ganglion cell morphology can be eliminated by carrying out studies similar to those reported here in the neonatal ferret. Ferret retina contains morphological classes of ganglion cells similar to those in the cat, but at birth the ferret retina is immature, and the morphological classes of ganglion cells have not yet differentiated (Vitek et al., 1985).

The third answer, which can also be tested experimentally, is that some of the differences between the soma and dendritic morphology of $\alpha$ and $\beta$ cells result from differences in the axonal morphology and patterns of central projection of the different cell types. It is now well documented that most $\alpha$ cells branch and project to many visual nuclei, including the $\Lambda$ and $C$ laminae of the LGNd, the medial interlaminar nucleus (MIN), the superior colliculus, and the pretectum. On the other hand, most $\beta$ cells project only to the A laminae of the LGNd (Friedlander et al., 1979; Illing and Wässle, 1981; Bowling and Michael, 1984; Leventhal et al., 1985). Also, in the A laminae of the LGNd $\alpha$ cell axonal arbors are more extensive than $\beta$ cell arbors (Bowling and Michael, 1981; Friedlander et al., 1981). Hence, it is possible that $\alpha$ cells grow to be larger than $\beta$ cells in order to balance their more extensive axonal arborizations.

This hypothesis can be tested by unilaterally ablating the superior colliculus in the neonatal kitten. This should reduce the number of $\alpha$ cells but not $\beta$ cell axonal branches since all $\alpha$ cells and few if any $\beta$ cells project to the superior colliculus (Illing and Wässle, 1981; Leventhal et al., 1985). In these animals the relative differences between $\alpha$ and $\beta$ cells should be reduced if there are any relationships among a cell's axonal morphology, central projections, and its soma and dendritic structure.

\section{Independence of dendritic field size and displacement}

This study contirms previous investigations showing that retinal ganglion cell dendrites extend preferentially into areas of reduced ganglion cell density (Linden and Pcrry, 1982; Perry and Linden, 1982; Ault et al., 1985; Eysel et al., 1985). It has also been demonstrated that, in the normal cat retina, ganglion cell dendrites tend to be displaced from the cell body down the normal ganglion cell density gradient (Schall and Leventhal, 1987); such a tendency is not observed, however, in the rat, which has a very shallow ganglion cell density gradient (Schall et al., 1987).

The new information this study provides is that the development of cell body and dendritic field size seems to be independent of the spatial distribution of the dendritic field relative to the soma. In particular, we find that the dendrites of all cell types extend preferentially into ganglion cell-free regions even though the cell bodies and dendritic fields of only $\alpha$ and $\beta$ cells increase in size if cell density is reduced. Thus, it appears that more than one "competitive" mechanism is involved in normal ganglion cell dendritic field development. One determines the direction of dendritic growth, and the other determines cell body size and the amount of dendrite produced.

The dual-mechanism hypothesis is attractive since it suggests that uniform coverage of the retina can be achieved for all classes of cells by the mechanism that normally results in the displacement of the dendrites down the ganglion cell density gradient. This mechanism may be responsible for the development of the ganglion cell mosaic, i.e., the complete and uniform coverage of ganglion cell dendritic fields over the retina (Wässle et al., 1981a, b; Schall and Leventhal, 1987). The second mechanism, which we hypothesize is specific for $\alpha$ and $\beta$ cells, then becomes responsible for the changes in the morphology of these cell types normally associated with eccentricity. This dual-mechanism hypothesis can provide for uniform coverage of the retina by all cell types even though changes in neuronal density do not affect the overall size of cell types other than $\alpha$ and $\beta$. The possible nature of the competitive mechanisms involved are unknown, have been the subject of speculation elsewhere (Perry and Linden, 1982; Eysel et al., 1985), and will require additional work to clarify. 


\section{Implications for retinal ganglion cell classification}

Boycott and Wässle (1974) were the first investigators to note the morphological similarity between $\alpha$ and $\beta$ cells. These authors reported that $\beta$ cells in far peripheral regions of cat retina closely resemble $\alpha$ cells close to the area centralis. The present study presents 2 additional findings consistent with the idea that $\alpha$ and $\beta$ cells are more closely related to each other than to other ganglion cell types. First, our results extend the observations of Boycott and Wässle (1974) and show that isolated $\beta$ cells within the area centralis region of a ganglion cell-free hemiretina bear a striking resemblance to $\alpha$ cells in the normal, high-density area centralis region of the same retina. Second, we have found a reduction in the number of neighboring cells during development profoundly and similarly affects cell body and dendritic field sizes of $\alpha$ and $\beta$ cells but does not affect the sizes of other types of cells at all. Thus, different developmental mechanisms seem to affect the morphological differentiation of $\alpha$ and $\beta$ cells and of other types of cells.

It is tempting to speculate that cat retina actually contains 2 supergroups of ganglion cells. Such an idea has already been put forth by Rowe and Stone (1980). These authors postulated that $\mathrm{X} / \mathrm{Y}$ cells constituted one group and $\mathrm{W}$ cells the other. According to this scheme, $\mathrm{X}$ and $\mathrm{Y}$ cells, which correspond to $\beta$ and $\alpha$ cells, are subtypes of the $X / Y$ supergroup, while all other cell types are subtypes of the $W$ cell supergroup. Our findings indicate that the mechanisms mediating ganglion cell development are consistent with this view.

\section{Physiological correlates of altered ganglion cell morphology}

Whether a ganglion cell is brisk or sluggish, linear or nonlinear, orientation biased or not may depend on the distribution and cable properties of the cell's dendrites. Specific hypotheses concerning the relationship between the dendritic morphology and the receptive field properties of retinal ganglion cells have been proposed (Koch et al., 1982).

In order to discover which physiological properties of ganglion cells depend on dendritic morphology, it should be possible to undertake a quantitative analysis of the dendritic fields of physiologically characterized, HRP-stained $\alpha$ and $\beta$ cells in normal regions and cells within and along the borders of ganglion cellfree zones after optic tract lesioning. The latter cells have abnormal dendritic field structures and provide the opportunity to see how the receptive field properties of a specific class of cells change when its dendritic field structure is altered systematically. The afferent connectivity of the altered cells may or may not be normal; electron microscopic studies of the connections of the altered cells should yield quite interesting results.

\section{Conclusion}

This investigation provides evidence that interactions with neighboring neurons during development profoundly affect the morphological development of some ganglion cell types in cat retina. Any number of factors in the molecular environment of the developing retina may be mediating the affects we have observed. The alterations in neuronal morphology we observed are likely to have profound physiological consequences. Future studies of retinal ganglion cell development in normal and cellfree regions of cat and ferret retina provide an opportunity to clarify the mechanisms that mediate the development of the anatomy, physiology, and central projections of retinal ganglion cells.

\section{References}

Nltman, J. (1976) Experimental reorganization of the cerebellar cortex. VII. Effects of late X-irradiation schedules that interfere with cell acquisition after stellate cells are formed. J. Comp. Neurol. 165: 6576.

Altman, J., and W. J. Anderson (1972) Experimental reorganization of the cerebellar cortex. I. Morphological effects of elimination of all microneurons with prolonged X-irradiation started at birth. J. Comp. Neurol. 146: 355-406.

Ault, S. J., J. D. Schall, and A. G. Leventhal (1985) Experimental alterations of cat retinal ganglion cell dendritic field structure. Soc. Neurosci. Abstr. 11: 15.

Bowling, D. B., and C. R. Michael (1984) Terminal patterns of single, physiologically characterized optic tract fibers in the cat's lateral geniculate nucleus. J. Neurosci. 4: 198-216.

Boycott, B. B., and H. Wässle (1974) The morphological types of ganglion cells of the domestic cat's retina. J. Physiol. (Lond.) 240: 397-419.

Bradley, P., and M. Berry (1976) The effects of reduced climbing and parallel fibre input on Purkinje cell dendritic growth. Brian Res. 109: $133-151$.

Carpenter, P., A. J. Sefton, B. Dreher, and W. Lim (1986) Role of target tissue in regulating the development of retinal ganglion cells in the albino rat: Effects of kainate lesions of the superior colliculus. $J$. Comp. Neurol. 251: 240-259.

Cleland, B. G., and W. R. Levick (1974a) Brisk and sluggish concentrically organized ganglion cells in the cat's retina. J. Physiol. (Lond.) 240: $421-456$.

Cleland, B. G., and W. R. Levick (1974b) Properties of rarely encountered types of ganglion cells in the cat's retina and an overall classification. J. Physiol. (Lond.) 240: 457-492.

Cleland, B. G., M. W. Dubin, and W. R. Levick (1971) Sustained and transient neurones in the cat's retina and lateral geniculate nucleus. J. Physiol. (Lond.) 217: 473-496.

Deitch, J. S., and E. W. Rubel (1984) Afferent influences on brainstem auditory nuclei of the chicken. Time course and specificity of dendritic atrophy following deafferentation. J. Comp. Neurol. 229: 66-79.

Enroth-Cugell, C., and J. G. Robson (1966) The contrast sensitivity of retinal ganglion cells of the cat. J. Physiol. (Lond.) 187: 517-552.

Eysel, U. T., L. Peichl, and H. Wässle (1985) Dendritic plasticity in the early postnatal feline retina: Quantitative characteristics and sensitive period. J. Comp. Neurol. 242: 134-145.

Friedlander, M. J., C. S. Lin, L. R. Stanford, and S. M. Sherman (1979) Structure of physiologically identified $\mathrm{X}$ and $\mathrm{Y}$ cells in the cat's lateral geniculate nucleus. Science 204: 1114-1117.

Gilbert, C. D., and T. N. Wiesel (1979) Morphology and intracortical projections of functionally characterized neurons in the cat visual cortex. Nature 280: 120-125.

Harris, R. M., and T. A. Woolsey (1981) Dendritic plasticity in mouse barrel cortex following postnatal vibrissa follicle damage. J. Comp. Neurol. 196: 357-376.

Hendry, S. H. C., S. Hockfield, E. G. Jones, and R. McKay (1984) Monoclonal antibody that identifies subsets of neurons in the central visual system of monkey and cat. Nature 307: 267-269.

Illing, R. B., and H. Wässle (1981) The retinal projection to the thalamus in the cat: A quantitative investigation and a comparison with the retinotectal pathway. J. Comp. Neurol. 202: 265-285.

Jacobs, D. S., V. H. Perry, and N. J. Hawken (1984) The postnatal reduction of the uncrossed projection from the nasal retina in the cat. J. Neurosci. 4: 2425-2433.

Kirby, M. A., and L. Chalupa (1986) Retinal crowding alters the morphology of alpha ganglion cells. J. Comp. Neurol. 251: 532-541.

Koch, C., T. Poggio, and V. Torres (1982) Retinal ganglion cells: A functional interpretation of dendritic morphology. Phil. Trans. R. Soc. Lond. [Biol.] 298: 227-264.

Kolb, H. (1979) The inner plexiform layer in the retina of the cat: Electron microscopic observations. J. Neurocytol. 8: 295-329.

Kolb, H., R. Nelson, and A. Mariani (1981) Amacrine cells, bipolar cells and ganglion cells of the cat retina: A Golgi study. Vision Res. 22I: $1081-1114$.

Leventhal, A. G. (1982) Morphology and distribution of retinal ganglion cells projecting to different layers of the dorsal lateral geniculate nucleus of normal and Siamese cats. J. Neurosci. 2: 1024-1042.

Leventhal, A. G., and J. D. Schall (1983) Structural basis of orientation 
sensitivity of cat retinal ganglion cells. J. Comp. Neurol. 220: 465475.

Leventhal, A. G., R. W. Rodieck, and B. Dreher (1985) Central projections of cat retinal ganglion cells. J. Comp. Neurol. 237: 216-226.

Leventhal, A. G., J. D. Schall, S. J. Ault, J. M. Provis, and D. J. Vitek (1988) Class-specific cell death shapes the distribution and pattern of central projection of cat retinal ganglion cells. J. Neurosci. 8: 20112027.

Linden, R., and V. H. Perry (1982) Ganglion cell death within the developing retina: A regulatory role for retinal dendrites? Neuroscience $7:$ 2813-2837.

Mariani, J., F. Crepel., K. Mikoshiba, J. P. Changeux, and C. Sotelo (1977) Anatomical, physiological and biochemical studies of the cerebellum from reeler mutant mouse. Phil. Trans. R. Soc. Lond. 281: $1-28$.

Maslim, J., M. Webster, and J. Stone (1986) Stages in the structural differentiation of retinal ganglion cells. J. Comp. Neurol. 254: 382402.

Parks, T. N. (1981) Changes in the length and organization of nucleus laminaris dendrites after unilateral otocyst ablation in chick embryos. J. Comp. Neurol. 202: 47-57.

Perry, V.H., and R. Linden (1982) Evidence for dendritic competition in the developing retina. Nature 297: 683-685.

Rakic, P., and R. L. Sidman (1973a) Sequence of developmental abnormalities leading to granule cell deficit in cerebellar cortex of weaver mutant mice. J. Comp. Neurol. 152: 103-132.

Rakic, P., and R. L. Sidman (1973b) Organization of cerebellar cortex secondary to deficit of granule cells in weaver mutant mice. J. Comp. Neurol. 152: 133-162.

Ramoa, A. S., G. Campbell, and C. J. Shatz (1987) Transient morphological features of identified ganglion cells in living fetal and neonatal retina. Science 237: 522-525.

Rapaport, D. H., and J. Stone (1983) Time course of morphological differentiation of cat retinal ganglion cells: Influences on soma size. J. Comp. Neurol. 221: 42-52.

Rowe, M. H., and J. Stone (1980) The interpretation of variation in the classification of nerve cells. Brain Behav. Evol. 17: 123-151.

Schall, J. D., and A. G. Leventhal (1987) Relationships between ganglion cell dendritic structure and retinal topography in the cat. J. Comp. Neurol. 257: 149-159.

Schall, J. D., V. H. Perry, and A. G. Leventhal (1987) Ganglion cell dendritic structure and retinal topography in the rat. J. Comp. Neurol. 257: 160-165.
Sotelo, C. (1975) Anatomical, physiological and biochemical studies of the cerebellum from mutant mice. II. Morphological study of cerebellar cortical neurons and circuits in the weaver mouse. Brain Res. 94: $19-44$

Sotelo, C., and M. L. Arsenio-Nunes (1976) Development of Purkinje cells in absence of climbing fibers. Brain Res. 111: 389-395.

Sotelo, C., and J. P. Changeux (1974) Trans-synaptic degeneration en cascade in cerebellar cortex of staggerer mutant mice. Brain Res. 67: $519-526$.

Steffan, H., and H. Van der Loos (1980) Early lesions of mouse vibrissal follicles: Their influence on dendritic orientation in the cortical barrelfield. Exp. Brain. Res. 40: 419-431.

Stevens, J. K., B. A. McGuire, and P. Sterling (1980) Toward a functional architecture of the retina: Serial reconstruction of adjacent ganglion cells. Science 207: 317-319.

Stone, J. (1966) The naso-temporal division of the cat's retina. J. Comp. Neurol. 126: 585-600.

Stone, J., and Y. Fukuda (1974) Properties of cat retinal ganglion cells: A comparison of W-cells with X- and Y-cells. J. Neurophysiol. 37: $722-748$

Vitek, D. J., J. D. Schall, and A. G. Leventhal (1985) Morphology, central projections and dendritic field orientation of retinal ganglion cells in the ferret. J. Comp. Neurol. 241: 1-11.

Walsh, C., and E. H. Polley (1985) The topography of ganglion cell production in the cat's retina. J. Neurosci. 5: 741-750.

Wässle, H., and R. B. Illing (1980) The retinal projection to the superior colliculus in the cat: A quantitative study with HRP. J. Comp. Neurol. 190: 333-356.

Wässle, H., L. Yeichl, and B. B. Boycott (1981a) Dendritic territories of cat retinal ganglion cells. Nature 292: 344-345.

Wässle, H., L. Peichl, and B. B. Boycott (1981b) Morphology and topography of on- and off- alpha cells in the cat retina. Proc. R. Soc. Lond. [Biol.] 212: 157-175.

Woolsey, T. A., and H. Van der Loos (1970) The structural organization of layer IV in the somatosensory region (SI) of mouse cerebral cortex. The description of a cortical field composed of discrete cytoarchitectonic units. Brain Res. 17: 205-242.

Woolsey, T. A., M. L. Dierker, and D. F. Wann (1975) Mouse SmI cortex: Qualitative and quantitative classification of Golgi-impregnated barrel neurons. Proc. Natl. Acad. Sci. USA 72: 2165-2169. 